\title{
Application of Organic and Inorganic Salts to Field-Grown Potato Tubers Can Suppress Silver Scurf During Potato Storage
}

\author{
Claudia Olivier, Department of Plant Pathology, Cornell University, Ithaca, NY 14853; Carol R. MacNeil, Cornell \\ Cooperative Extension-Vegetable Program in Ontario, Wayne, Yates and Steuben Co., Canandaigua, NY 14424; \\ and Rosemary Loria, Department of Plant Pathology, Cornell University
}

\begin{abstract}
Olivier, C., MacNeil, C. R., and Loria, R. 1999. Application of organic and inorganic salts to field-grown potato tubers can suppress silver scurf during potato storage. Plant Dis. 83:814-818.

Silver scurf, caused by Helminthosporium solani, is an economically important postharvest disease of potato tubers. Organic and inorganic salts were evaluated for their ability to suppress silver scurf lesion development and sporulation of $H$. solani on potato tubers. Tubers were treated immediately after harvest with $0.2-\mathrm{M}$ solutions of potassium sorbate, calcium propionate, sodium bicarbonate, sodium carbonate, ammonium bicarbonate, or water. Tween 20 was added as a surfactant to most treatments. Potassium sorbate $(0.1 \mathrm{M})$, acidified potassium sorbate and calcium propionate treatments $(0.2 \mathrm{M})$, and calcium chloride treatments $(0.136 \mathrm{M})$ were included in additional experiments. Tubers were stored under commercial storage conditions for 4 to 6 months prior to disease evaluation. The extent of disease suppression varied among experiments; however, some treatments consistently reduced disease. Lesion formation on the tuber surface was reduced by 26 to $60 \%$ using potassium sorbate (in three of four experiments) compared to water-treated or untreated tubers. Sporulation was suppressed by $0.2 \mathrm{M}$ potassium sorbate (78 to $99 \%$ reduction) in all four experiments. Sodium carbonate reduced lesion formation in two experiments and sporulation in three of four experiments. Other treatments inconsistently suppressed lesion formation or sporulation, or did not reduce disease. Addition of Tween or acidification of organic salt solutions did not improve silver scurf suppression in most cases. Potassium sorbate has very low mammalian toxicity and great potential as an innocuous and inexpensive postharvest fungicide for suppression of silver scurf during potato storage.
\end{abstract}

Silver scurf, caused by Helminthosporium solani Durieu \& Mont., is a postharvest disease affecting the periderm of potato tubers. The disease is characterized by tan to gray circular lesions which may coalesce with increased disease severity. Lesions are often clustered at the stolon end of the tuber and have a silvery sheen attributed to air pockets that develop in the periderm as a result of the cellulolytic activity of $H$. solani (6). Infection can occur during the growing season and lesions may be visible at the time of harvest (23). Disease symptoms increase greatly during long-term storage of tubers as a result of lesion expansion and repeated cycles of sporulation and reinfection $(6,11,13)$.

The ecology of H. solani is not well understood due to difficulties in isolating this slow-growing pathogen from soil. Although the seed tuber is considered the major source of inoculum, survival of $H$. solani in soil has been demonstrated

Corresponding author: Rosemary Loria

E-mail: r121@cornell.edu

This research was supported in part by the USDA/ARS Potato Research Grants Program.

Accepted for publication 17 May 1999.

Publication no. D-1999-0628-01R

(C) 1999 The American Phytopathological Society
(14,24). The saprophytic potential of $H$. solani was shown in vitro by colonization of senescing or dried plant tissue of a range of crops (24; C. Olivier, unpublished).

Silver scurf is of great economic importance (30). Losses result from reduction in tuber fresh weight during storage and from discoloration of the tuber periderm $(11,13)$, which greatly reduces tuber marketability. Economic losses have increased in Europe and North America since $H$. solani has developed resistance to thiabendazole (TBZ), which is frequently applied to potatoes as a postharvest and seed-piece treatment $(12,15,22)$. TBZ has been used for many years in the United States for control of Fusarium dry rot on potato tubers; it is likely that the fungicide concomitantly controlled silver scurf, until resistance developed. At present, no fungicide is registered for postharvest control of silver scurf in the United States, and alternative control strategies are needed.

Selected organic and inorganic salts are active antimicrobial agents and have been widely used in the food industry. Many of these salts are effective against a range of microorganisms; most have low mammalian toxicity and therefore have potential for postharvest disease control. Salt treatments can inhibit plant pathogens or suppress mycotoxin production $(26,31,37,39,44)$. Sodium and ammonium bicarbonate were shown to inhibit fungal pathogens of fruits, field crops, vegetables, and ornamentals $(9,32,33,35,46)$. Sodium carbonate effectively suppressed green mold of citrus fruits caused by Penicillium digitatum (Pers.:Fr.) Sacc. (40,41) and reduced growth of storage fungi (1). Salts of sorbic and propionic acid are the most commonly used preservatives in the food industry and reduce growth of molds, yeast, or bacteria in food and feed products $(16,19,25,43)$. They can also inhibit pathogens that cause postharvest plant diseases $(2,31,33)$. Calcium salts, including calcium propionate and calcium chloride, were shown to reduce brown rot of peach and green mold of citrus. These salts also reduced tissue maceration of potato tubers caused by Erwinia carotovora $(4,10,20)$. The efficacy of salt treatments depends on the concentration, the target organism, and the method of application $(21,25,31,33,42)$; dip treatments of whole fruits or vegetables, misting, or dusting of plants and plant products are the commonly used application methods. Addition of surfactants may increase the efficacy of salt treatments $(2,45,46)$.

We previously demonstrated that sodium- and potassium carbonate and bicarbonate, ammonium bicarbonate, potassium sorbate, and calcium propionate inhibited growth of $H$. solani in vitro (31). Under controlled experimental conditions, sporulation of $H$. solani and silver scurf lesion development were inhibited by dip treatments of whole potato tubers. In this article, we describe the application of several salts and a surfactant for postharvest control of silver scurf. Salt solutions were applied by dipping or misting naturally infected tubers harvested from commercial fields. Tubers were stored for at least 4 months under conditions simulating potato storage or directly in commercial storage facilities.

\section{MATERIALS AND METHODS}

Experimental design. For all experiments, potato tubers were harvested when physiologically mature. Tubers were grown in 1996 for experiments 1 and 2 and in 1997 for experiments 3 and 4. Potatoes were grown by farmers in field sites to which potatoes had been planted previously as part of a crop rotation; these fields likely contained soilborne inoculum of $H$. solani. After harvest, tubers were sorted for size uniformity and randomly assigned to treatments. The surfactant Tween 20 
(polyoxyethylene sorbitan monolaureate) was added to most treatments in 1996 at a concentration of $0.25 \%$. Control treatments (water with and without Tween 20) were included. In all experiments, tubers were evaluated individually for silver scurf lesions (percentage of tuber surface with lesions) immediately after storage. From each treatment, 12 tubers (in 1996) or 20 tubers (in 1997) with visible lesions were selected for spore counts. Tubers used in experiments 1 and 2 had already developed visible silver scurf lesions at the time of harvest. All chemicals used in this study were obtained from Sigma-Aldrich, St. Louis.

Experiment 1. Potato tubers (cv. Chieftain) were grown on a mineral soil in Freeville, New York. Tubers were stored for 10 days at 15 to $20^{\circ} \mathrm{C}$ before treatments. A total of 48 tubers per treatment were washed, air dried overnight, and dipped for $1 \mathrm{~min}$ in one of the following eight solutions: $0.2 \mathrm{M}$ potassium sorbate $\left(\mathrm{C}_{6} \mathrm{H}_{7} \mathrm{O}_{2} \mathrm{~K}\right), 0.2 \mathrm{M}$ potassium sorbate with Tween, $0.2 \mathrm{M}$ calcium propionate $\left(\mathrm{C}_{3} \mathrm{H}_{5} \mathrm{O}_{2} \cdot 1 / 2 \mathrm{Ca}\right)$ with Tween, $0.2 \mathrm{M}$ sodium bicarbonate $\left(\mathrm{NaHCO}_{3}\right)$ with Tween, $0.2 \mathrm{M}$ ammonium bicarbonate $\left(\mathrm{NH}_{4} \mathrm{HCO}_{3}\right)$ with Tween, $0.2 \mathrm{M}$ sodium carbonate $\left(\mathrm{Na}_{2} \mathrm{CO}_{3}\right)$ with Tween, $0.25 \%$ Tween 20 , and water. Treated tubers were placed into plastic mesh bags, air-dried for $6 \mathrm{~h}$, and stored at $15^{\circ} \mathrm{C}$ and high relative humidity in growth

A

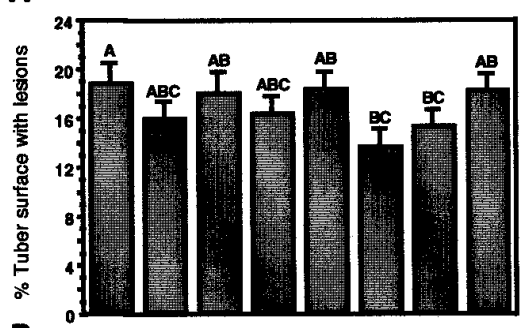

B

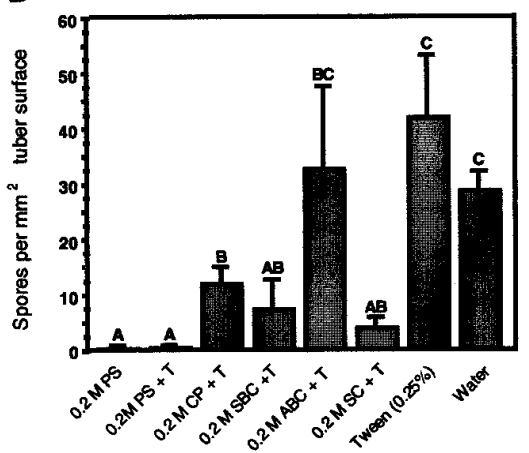

Fig. 1. (A) Lesion surface area and (B) sporulation of Helminthosporium solani on silver scurf-infected potato tubers treated with salt solutions (experiment 1). Graphs represent means of untransformed data with standard error bars. In B (spores per $\mathrm{mm}^{2}$ tuber surface), letters correspond with statistical analyses performed on log-transformed data. Mean values followed by the same letter do not differ significantly. chambers for 4 months before disease evaluation.

Experiment 2. Potato tubers (cv. Chieftain) were grown on a muck soil in Wayne County, New York, and stored for 10 days before treatment. The experiment was performed with 48 tubers per treatment as described for experiment 1 , but included the following three additional treatments: $0.2 \mathrm{M}$ potassium sorbate $(\mathrm{pH}$ 5.7; adjusted with sorbic acid), $0.2 \mathrm{M}$ calcium propionate $(\mathrm{pH} 5.2$; adjusted with propionic acid), and untreated, unwashed tubers.

Experiment 3. Potato tubers (cv. Monona) were grown on a muck soil in Wayne County, New York. Tubers (105 tubers/treatment) were treated immediately after harvest and were not washed prior to treatment. Treatments consisted of $0.2 \mathrm{M}$ potassium sorbate, $0.1 \mathrm{M}$ potassium sorbate, $0.2 \mathrm{M}$ potassium sorbate $(\mathrm{pH} 6$; adjusted with sorbic acid), $0.2 \mathrm{M}$ sodium carbonate, $0.2 \mathrm{M}$ sodium bicarbonate, 0.1 $\mathrm{M}$ calcium propionate, $0.2 \mathrm{M}$ calcium propionate $(\mathrm{pH} 6$; adjusted with propionic acid), $0.136 \mathrm{M} \mathrm{(2 \% )}$ calcium chloride, water, and untreated, unwashed tubers. Each tuber was individually misted with a hand-held sprayer until the entire tuber surface was moistened. Tubers were placed in mesh bags, air dried, and placed in a commercial potato storage facility $\left(\right.$ at $\left.4^{\circ} \mathrm{C}\right)$ for 20 weeks. Immediately before disease evaluation, tubers were washed.

A

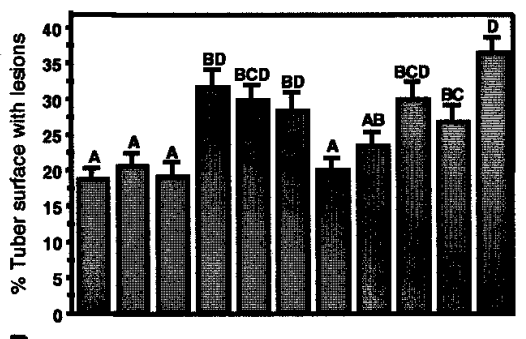

B

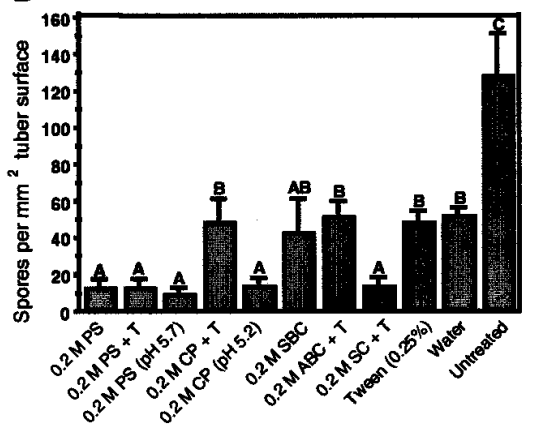

Fig. 2. (A) Lesion surface area and (B) sporulation of Helminthosporium solani on silver scurf-infected potato tubers treated with salt solutions (experiment 2). Graphs represent means of untransformed data with standard error bars. In B (spores per $\mathrm{mm}^{2}$ tuber surface), letters correspond with statistical analyses performed on log-transformed data. Mean values followed by the same letter do not differ significantly.
Experiment 4. Tubers (cv. Chieftain) were grown in Wayne County, New York, and washed and air dried prior to treatments. Treatments consisted of $0.2 \mathrm{M}$ potassium sorbate, $0.1 \mathrm{M}$ potassium sorbate, $0.2 \mathrm{M}$ sodium bicarbonate, $0.2 \mathrm{M}$ sodium carbonate, $0.136 \mathrm{M}$ calcium chloride, water, and untreated potato tubers. Tubers (100 tubers/treatment) were misted as described above, placed in mesh bags, airdried, and stored under commercial potato storage conditions at $5^{\circ} \mathrm{C}$ for 6 months before disease evaluation.

Evaluation of sporulation. Tubers selected for sporulation assessment were stored for another 3 weeks at 21 to $23^{\circ} \mathrm{C}$ in moist chambers to encourage sporulation. Spore production was evaluated by removing circular slices $(7 \mathrm{~mm}$ in diameter, 2 to $4 \mathrm{~mm}$ thick) from lesions, using a cork borer and a scalpel. Tuber periderm disks (15/tuber) were placed in a 2-ml Eppendorf tube and vortexed with $1 \mathrm{ml}$ of distilled water for $8 \mathrm{~min}$ to dislodge spores. The suspension was centrifuged at 5,000 $\times g$ for $10 \mathrm{~min}$, tuber disks were removed, the volume reduced to $200 \mu \mathrm{l}$, and spore suspensions were stored at $-10^{\circ} \mathrm{C}$. Spores (for 12 or 20 individual potato tubers per treatment) were counted using a hemacytometer. Spore counts were repeated at least two times for each spore suspension. All statistical analyses $(18,29)$ were performed with SAS (SAS Institute, Cary, NC). Lesion development and sporulation data were analyzed with analysis of variance (general linear model), and treatment means were compared with Tukey's Studentized Range Test. Sporulation data were log-transformed prior to statistical analysis. Graphical presentations include original data.

\section{RESULTS}

Lesion development. None of the treatments significantly reduced lesion surface area in experiment 1 compared to the water or surfactant controls (Fig. 1A). Average tuber surface area with silver scurf lesions across all treatments was $17 \%$. In experiment 2, all three potassium sorbate treatments and ammonium bicarbonate with Tween significantly $(P<0.01)$ reduced the lesion surface area compared to untreated controls, water, or Tween control treatments (Fig. 2A). In this experiment, water treatment alone significantly reduced lesion surface area compared to the untreated control tubers. Tween alone did not reduce lesion surface area in experiments 1 or 2 (Figs. 1A and 2A). In experiment 3 (Fig. 3A), all three potassium sorbate treatments, sodium bicarbonate, and calcium chloride significantly $(P<0.01)$ reduced lesion surface area compared to water-treated or untreated controls. In this experiment, calcium propionate $(\mathrm{pH} 6)$ treatments suppressed silver scurf at $0.2 \mathrm{M}$, but not at $0.1 \mathrm{M}$, when compared to control treatments. Sodium carbonate significantly $(P<0.01)$ reduced lesions compared to 
water-treated tubers, but not compared to untreated tubers. The percentage of lesion area did not differ between water-treated and untreated tubers. In experiment 4 , results of lesion evaluation were similar to those in experiment 3 for all seven treatments (Fig. 4A). Potassium sorbate treatments, sodium bicarbonate, and calcium chloride significantly $(P<0.01)$ reduced the surface area with lesions compared to water-treated or untreated controls. The percentage of lesion area did not differ between water-treated and untreated tubers.

Sporulation. Treatments differed in their ability to suppress sporulation in all experiments. Potassium sorbate at $0.2 \mathrm{M}$ (at all $\mathrm{pH}$ values) significantly $(P<0.01)$ reduced sporulation in all four experiments. Suppression of sporulation ranged from 78 to $99 \%$ (Figs. 1B to 4B) among the four experiments. In three out of four experiments, sporulation was almost completely suppressed (0.02 to 0.05 spores/ $\mathrm{mm}^{2}$ tuber) after potassium sorbate treatments. Potassium sorbate at a lower concentration $(0.1 \mathrm{M})$ similarly reduced spore formation compared to water-treated tubers in experiments 3 and 4 (Figs. 3B and 4B), but not compared to untreated tubers in experiment 4 (Fig. 4B). Sodium carbonate (0.2 M) suppressed sporulation of $H$. solani, although results were less consistent than with potassium sorbate.

A

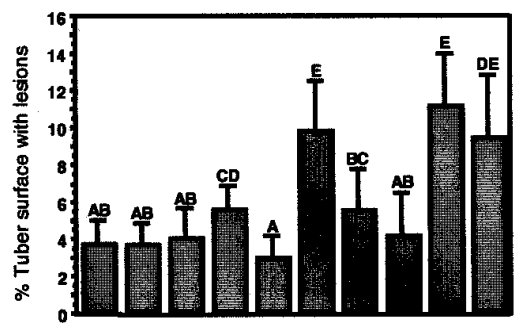

B

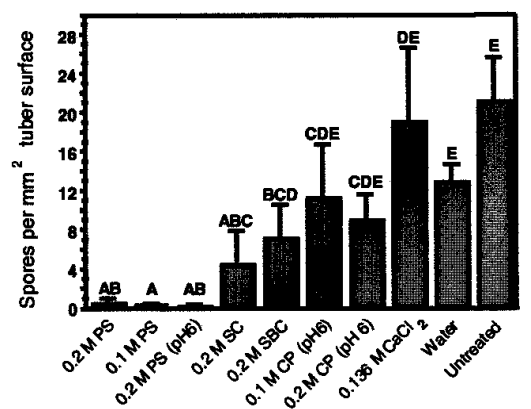

Fig. 3. (A) Lesion surface area and (B) sporulation of Helminthosporium solani on silver scurf-infected potato tubers treated with salt solutions (experiment 3). Graphs represent means of untransformed data with standard error bars. In B (spores per $\mathrm{mm}^{2}$ tuber surface), letters correspond with statistical analyses performed on log-transformed data. Mean values followed by the same letter do not differ significantly.
Sodium carbonate significantly $(P<0.01)$ reduced spore numbers in experiments 1 to 3 (Figs. 1B to 3B ) and significantly $(P<$ 0.01 ) reduced spore development compared to water-treated tubers, but not to untreated tubers in experiment 4 (Fig. 4B). Calcium propionate with Tween suppressed sporulation in experiment $1 \mathrm{com}$ pared to all controls and in experiment 2 compared to the untreated control (Figs. $1 \mathrm{~B}$ and $2 \mathrm{~B}$ ). Acidified calcium propionate $(\mathrm{pH} 5.2)$ significantly $(P<0.01)$ reduced sporulation compared to all control treatments in experiment 2 (Fig. 2B). However, no effect on sporulation was observed by any calcium propionate treatment in experiment 3 (Fig. 3B). Ammonium bicarbonate, calcium chloride, and Tween 20 did not reduce sporulation (Figs. $1 \mathrm{~B}$ to 4B).

\section{DISCUSSION}

We have evaluated postharvest applications of organic and inorganic salts for their ability to suppress silver scurf on naturally infected, field-grown potato tubers stored under commercial conditions. Because of the importance of sporulation and reinfection during storage in the epidemiology of this disease, we evaluated the effects of postharvest treatments on both lesion surface area and sporulation. In a previous study, we demonstrated a significant and similar reduction of silver scurf with several organic and inorganic salts

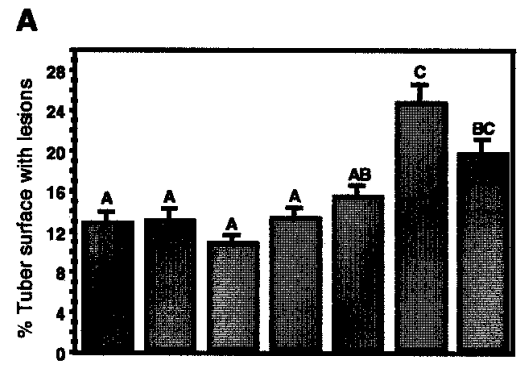

B

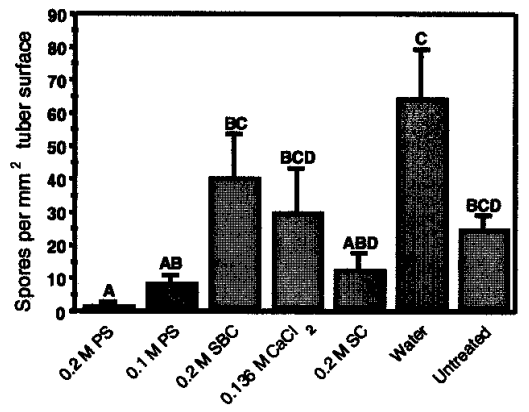

Fig. 4. (A) Lesion surface area and (B) sporulation of Helminthosporium solani on silver scurf-infected potato tubers treated with salt solutions (experiment 4). Graphs represent means of untransformed data with standard error bars. In B (spores per $\mathrm{mm}^{2}$ tuber surface), letters correspond with statistical analyses performed on log-transformed data. Mean values followed by the same letter do not differ significantly. under controlled conditions (31). The present study allowed us to identify the most efficacious treatments. In this study, tubers were severely infected with silver scurf before treatment application and were stored under commercial potato storage conditions where sporulation and reinfection could occur (36). Potassium sorbate was the most efficacious treatment, which reduced the silver scurf lesion area by 26 to $60 \%$ in three out of four experiments and significantly reduced sporulation in all four experiments. Potassium sorbate $(0.2$ M) almost completely (96 to $99 \%$ ) eliminated sporulation in experiments 1,3 , and 4. Two of the four experiments included $0.2 \mathrm{M}$ acidified potassium sorbate $(\mathrm{pH} \leq 6)$ in addition to unadjusted $0.2 \mathrm{M}$ potassium sorbate ( $\mathrm{pH}$ 8.3). Several studies describe that sorbic acid and its salts are more effective in suppression of microorganisms at acidic $\mathrm{pH}(5,33)$. However, in our study, no differences were detected in lesion surface area or sporulation as a result of acidification. A reduced concentration of potassium sorbate $(0.1 \mathrm{M})$ was insufficient for consistent disease suppression.

Sodium carbonate was the second most efficacious treatment. This treatment did not consistently result in lesion reduction, but inhibited sporulation in most experiments. Although pathogen inhibition by carbonate salts is primarily due to the production of the carbonate anion $(7,34)$, suppression of fungi by $0.2 \mathrm{M}$ sodium carbonate is likely also related to the alkaline $\mathrm{pH}$ ( $\mathrm{pH}>11)$, which is detrimental to most microorganisms. Sodium carbonate was shown to be more effective against green mold of citrus fruits ( $P$. digitatum) when applied at concentrations of 4 or $6 \%$ than at $2 \%(40)$. We treated tubers with only $2.1 \%$ (equals $0.2 \mathrm{M}$ ) solutions of sodium carbonate. In our studies, sodium carbonate caused a slight discoloration (darkening) of the tuber periderm when applied at a concentration of $0.2 \mathrm{M}$. Although an increased concentration of sodium carbonate would likely result in better control of silver scurf (40), this discoloration could decrease the market value of the tubers. In contrast to sodium carbonate, potassium sorbate resulted in a desirable light coloration of the tuber periderm, and the red coloration of potato cv. Chieftain was especially pronounced after storage. All other treatments did not affect periderm pigmentation.

Sodium bicarbonate has been reported to be an efficient antifungal compound on ornamentals, cucurbits, and against postharvest pathogens $(3,7,8,27,32,35,46)$. In our study, $0.2 \mathrm{M}$ sodium bicarbonate resulted in inconsistent disease suppression. Likewise, ammonium bicarbonate has the potential to suppress plant pathogens $(32,46)$, but did not reduce silver scurf lesions or $H$. solani sporulation. Other in vivo studies reported that sodium- and ammonium bicarbonate were much less efficient in postharvest disease suppression 
on carrots than potassium sorbate and acidified calcium propionate (33). The effectiveness of bicarbonate salts against plant pathogens may depend on the addition of oil to the treatments $(45,46)$.

Calcium propionate reduced the growth of Monilinia fructicola (Wint.) Honey in vitro and on inoculated peach fruits (4). It is also applied as an antifungal compound against storage molds (25). In our study, suppression of silver scurf by calcium propionate was inconsistent. Reduction of H. solani sporulation by acidified calcium propionate in 1996 could not be repeated in the following year. Our previous study and those of others (38) had demonstrated that calcium propionate is less effective than potassium sorbate, although both compounds are common antimicrobial agents in the food industry.

In 1997, a calcium chloride treatment was included in both experiments at a concentration $(0.136 \mathrm{M})$ reported to suppress growth of the citrus mold pathogen $P$. digitatum (10). Calcium chloride effectively reduced silver scurf lesions on potato tubers, but not sporulation of $\mathrm{H}$. solani. It is known that addition of calcium chloride can also improve the activity of biocontrol agents $(10,21)$.

Several reports describe an increased efficacy of salt treatments when combined with surfactants $(2,45,46)$. In our study, Tween 20 was included in most treatments in 1996 (experiments 1 and 2). Treatment with the surfactant alone did not reduce lesion development or sporulation. Improvements in treatment efficacy did not result from addition of Tween; therefore, it was not included in the 1997 experiments.

Two control treatments were included in experiments 2 to 4 , because it is common practice on potato farms to either wash the tubers at the time of harvest prior to longterm storage or immediately after storage. The effect of water control treatments on the development of silver scurf lesions and sporulation of $H$. solani compared to unwashed tubers varied among experiments. However, no significant differences were detected between water-treated and untreated tubers, except in experiment 2, where less sporulation was observed on water-treated tubers. This result could be due to a relatively small sample size for sporulation studies in experiment 2, which was increased in the following year. Water treatment (followed by air-drying of the tubers) never resulted in a significant disease increase.

Sorbic acid and its salts alter cell membranes and cell transport functions, and inhibit RNA, DNA, and protein synthesis and enzymes involved in the tricarboxylic acid cycle. Sorbic acid may also uncouple oxidative phosphorylation reactions in mitochondria $(16,42,43)$. Whereas inhibition of spoilage fungi and bacteria with potassium sorbate has been frequently demonstrated $(5,17,28,38)$, only a few studies assessed the potential of potassium sorbate to control fungi causing plant diseases $(2,34)$. Our study demonstrates that potassium sorbate at a concentration of 0.2 $\mathrm{M}$ consistently reduced silver scurf lesion development on previously infected potato tubers; (tubers are commonly infected with silver scurf at the time of harvest). This treatment effectively suppressed disease for a period of up to 6 months. Potassium sorbate also inhibited sporulation to 78 to 99\% and improved the appearance of redand white-skinned potato tubers. Postharvest application of potassium sorbate equally suppressed disease on washed and unwashed tubers and was independent of the application method (dip treatment or misting of tubers). Potassium sorbate is contained as a preservative in most perishable foods and is considered nontoxic, with a $50 \%$ lethal dose equivalent of $500 \mathrm{~g}$ for an adult human (42). It is therefore well suited as an innocuous fungicide against silver scurf. Although no negative effect on wound healing of potassium sorbatetreated tubers was observed in any experiment, further studies are needed to confirm this result. Postharvest applications of potassium sorbate could be combined with seed treatments of potatoes and cultural practices to minimize losses to silver scurf.

\section{ACKNOWLEDGMENTS}

We thank E. Mizubuti for help with statistical analyses.

\section{LITERATURE CITED}

1. Abdelhamid, A. M., Sadik, E. A., and Fayzalla, E. A. 1985. Preserving power of some additives against fungal invasion and mycotoxin production in stored-crushed-corn (Zea mays) containing different levels of moisture. Acta Phytopathol. Acad. Sci. Hung. 20:309-320.

2. Al-Zaemey, A. B., Magan, N., and Thompson, A. K. 1993. Studies on the effect of fruitcoating polymers and organic acids on growth of Colletotrichum musae in vitro and on postharvest control of anthracnose of bananas. Mycol. Res. 97:1463-1468.

3. Arimoto, Y., Homma, Y., and Misato, T. 1977. The effect of sodium hydrogencarbonate on the occurrence of citrus storage diseases. J. Pestic. Sci. 2:163-167.

4. Biggs, A. R., El-Kholi, M. M., El-Neshawy, S., and Nickerson, R. 1997. Effects of Calcium salts on growth, polygalacturonase activity, and infection of peach fruit by Monilinia fructicola. Plant Dis. 81:399-403.

5. Blocher, J. C., and Busta, F. F. 1985. Multiple modes of inhibition of spore germination and outgrowth by reduced $\mathrm{pH}$ and sorbate. J. Appl. Bacteriol. 59:469-478.

6. Burke, O. D. 1938. The silver scurf disease of potatoes. Cornell Univ. Agric. Exp. Stn. Bull. 692, Ithaca, NY.

7. Corral, L. G., Post, L. S., and Montville, T. J. 1988. Antimicrobial activity of sodium bicarbonate. J. Food Sci. 53:981-982.

8. Curran, D. M., and Montville, T. J. 1989. Bicarbonate inhibition of Saccharomyces cerevisiae and Hansenula wingei growth in apple juice. Int. J. Food Microbiol. 8:1-10.

9. DePasquale, D. A., El-Nabarawy, A., Rosen, J. D., and Montville, T. J. 1990. Ammonium bicarbonate inhibition of mycotoxigenic fungi and spoilage yeasts. J. Food Prot. 53:324-328.
10. Droby, S., Wisniewski, M. E., Cohen, L. Weiss, B., Touitou, D., Eilam, Y., and Chalutz, E. 1997. Influence of $\mathrm{CaCl}_{2}$ on Penicillium digitatum, grapefruit peel tissue, and biocontrol activity of Pichia guilliermondii. Plant Dis. 87:310-315.

11. Heiny, D. K., and McIntyre, G. A. 1983. Helminthosporium solani Dur. \& Mont. development on potato periderm. Am. Potato J. 60:773-789.

12. Hide, G. A., Hall, S. M., and Boorer, K. J. 1988. Resistance to thiabendazole in isolates of Helminthosporium solani, the cause of silver scurf disease of potatoes. Plant Pathol. 37:377-380.

13. Jellis, G. J., and Taylor, G. S. 1977. The development of silver scurf (Helminthosporium solani) disease of potato. Ann. Appl. Biol. 86:19-28.

14. Kamara, A. M., and Huguelet, J. E. 1972 Host range and overwintering of Helminthosporium solani. Am. Potato J. 49:365.

15. Kawchuk, L. M., Holley, J. D., Lynch, D. R., and Clear, R. M. 1994. Resistance to thiabendazole and thiophanate-methyl in Canadian isolates of Fusarium sambucinum and Helminthosporium solani. Am. Potato J. 71:185-192.

16. Kinderlerer, J. L., and Hatton, P. V. 1990. Fungal metabolites of sorbic acid. Food Addit. Contam. 7:657-670.

17. Kivanç, M., and Akgül, A. 1990. Mould growth on black table olives and prevention by sorbic acid, m eugenol and spice essential oil. Die Nahrung 34:369-373.

18. Kuehl, R. O. 1994. Statistical Principles of Research Design and Analysis. Duxbury Press, Belmont, CA.

19. Lund, B. M., George, S. M., and Franklin, J. G. 1987. Inhibition of type A and type B (proteolytic) Clostridium botulinum by sorbic acid. Appl. Environ. Microbiol. 53:935-941.

20. McGuire, R. G., and Kelman, A. 1986. Calcium in potato cell walls in relation to tissue maceration by Erwinia carotovora. Phytopathology 76:401-406.

21. McLaughlin, R. J., Wisniewski, M. E., Wilson, C. L., and Chalutz, E. 1990. Effect of inoculum concentration and salt solutions on biological control of postharvest diseases of apple with Candida sp. Phytopathology 80:456-461.

22. Merida, C. L., and Loria, R. 1990. First report of resistance of Helminthosporium solani to thiabendazole in the United States. Plant Dis. 74:614.

23. Merida, C. L., and Loria, R. 1994. Effects of potato cultivar and time of harvest on the severity of silver scurf. Plant Dis. 78:146-149.

24. Merida, C. L., and Loria, R. 1994. Survival of Helminthosporium solani in soil and in vitro colonization of senescent plant tissue. Am. Potato J. 71:591-598.

25. Milward, Z. 1976. Further experiments to determine the toxicity of propionic acid to fungi infesting stored grain. Trans. Br. Mycol. Soc. 66:319-324.

26. Montville, T. J., and Goldstein, P. K. 1989. Sodium bicarbonate inhibition of aflatoxigenesis in corn. J. Food Prot. 52:45-48.

27. Montville, T. J., and Shih, P. L. 1991. Inhibition of mycotoxigenic fungi in corn by ammonium and sodium bicarbonate. J. Food Prot. 54:295-297.

28. Mutasa, E. S., Magan, N., and Seal, K. J. 1990. Effects of potassium sorbate and environmental factors on growth of tobacco spoilage fungi. Mycol. Res. 94:971-978.

29. Neter, J., Wasserman, W., and Kutner, M. H. 1990. Applied Linear Statistical Models, 3rd ed. Irwin, Homewood, IL.

30. Nolte, P., Shetty, K., and Patterson, P. 1994 
Understanding and controlling silver scurf of potato. The Badger Common'tater 1:5-12.

31. Olivier, C., Halseth, D. E., Mizubuti, E. S. G., and Loria, R. 1998. Postharvest application of organic and inorganic salts for suppression of silver scurf on potato tubers. Plant Dis. 82:213-217.

32. Palmer, C. L., Horst, R. K., and Langhans, R. W. 1997. Use of bicarbonates to inhibit in vitro colony growth of Botrytis cinerea. Plant Dis. 81:1432-1438.

33. Punja, Z. K., and Gaye, M. M. 1993. Influence of postharvest handling practices and dip treatments on development of black root rot on fresh market carrots. Plant Dis. 77:989995.

34. Punja, Z. K., and Grogan, R. G. 1982. Effects of inorganic salts, carbonate-bicarbonate anions, ammonia, and the modifying influence of $\mathrm{pH}$ on sclerotial germination of Sclerotium rolfsii. Phytopathology 72:635-639.

35. Ricker, M. D., and Punja, Z. K. 1991. Influence of fungicide and chemical salt dip treatments on crater rot caused by Rhizoctonia carotae in long-term storage. Plant Dis. 75:470-474.

36. Rodriguez, D. A., Secor, G. A., Gudmestad, N. C., and Francl, L. J. 1996. Sporulation of Helminthosporium solani and infection of potato tubers in seed and commercial storages. Plant Dis. 80:1063-1070.

37. Roinestad, K. S., Montville, T. J., and Rosen, J. D. 1993. Inhibition of trichothecene biosynthesis in Fusarium tricinctum by sodium bicarbonate. J. Agric. Food Chem. 41:23442346.

38. Sebti, F., and Tantaoui-Elaraki, A. 1994. In vitro inhibition of fungi isolated from 'Pastilla' papers by organic acids and cinnamon. Lebensm. Wiss. Technol. 27:370-374.

39. Singh, S. N., and Chand, L. 1993. Inhibition of aflatoxin production by garlic extract and sodium bicarbonate. Crop Res. 6:149-154.

40. Smilanick, J. L., MacKey, B. E., Reese, R., Usall, J., and Margosan, D. A. 1997. Influence of concentration of soda ash, temperature, and immersion period on the control of postharvest green mold of oranges. Plant Dis.
81:379-382.

41. Smilanick, J. L., Margosan, D. A., and Henson, D. J. 1995. Evaluation of heated solutions of sulfur dioxide, ethanol, and hydrogen peroxide to control postharvest green mold of lemons. Plant Dis. 79:742-747.

42. Sofos, J. N. 1992. Sorbic acid, mode of action. Pages 43-52 in: Encyclopedia of Microbiology, Vol. 4., J. Lederberg, ed. Academic Press, San Diego, CA.

43. Sofos, J. N., Pierson, M. D., Blocher, J. C., and Busta, F. F. 1986. Mode of action of sorbic acid on bacterial cells and spores. Int. J. Food Microbiol. 3:1-18.

44. Walker, R. 1990. Toxicology of sorbic acid and sorbates. Food Addit. Contam. 7:671676.

45. Ziv, O., and Hagiladi, A. 1993. Controlling powdery mildew in Euonymus with polymer coatings and bicarbonate solutions. Hortscience 28:124-126.

46. Ziv, O., and Zitter, T. A. 1992. Effects of bicarbonates and film-forming polymers on cucurbit foliar diseases. Plant Dis. 76:513-517. 